\title{
Current Status of External Quality Control for the Classification of Complex Antibodies on the Unexpected Antibody Identification Test
}

\author{
Hee-Jeong Youk ${ }^{1 \oplus}$, Jin Seok Kim ${ }^{1 \oplus}$, Yousun Chung ${ }^{\circledR}$, Sang-Hyun Hwang1 ${ }^{\oplus}$, Heung-Bum Oh1®, \\ Hyungsuk Kim ${ }^{3 \oplus}$, and Dae-Hyun Ko ${ }^{1 \oplus}$ \\ ${ }^{1}$ Department of Laboratory Medicine, Asan Medical Center, University of Ulsan College of Medicine; ${ }^{2}$ Department of Laboratory

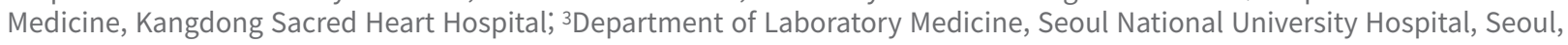 \\ Korea
}

비예기항체 선별 및 동정검사는 치명적인 용혈수혈반응을 예방 하기 위한 가장 기본적인 수혈 전 검사이다. 외부정도관리는 수혈 전 검사의 질을 유지하기 위해 필수적인 활동이며 국내에서는 대 한임상검사정도관리협회에서 주도적으로 외부정도관리를 시행 하고 있다. 비예기항체 선별 및 동정검사에 대해서는 1 년에 2차례 특정 항체 특이성을 가진 검체를 제조하여 외부정도관리 참가기관 들에게 발송하고 있다. 그러나 최근 복합 항체의 가능성을 배제할 수 없는 검체들에 대하여 오답을 제출하는 기관들이 상당수 있어 문제가 되고 있는 바[1], 저자들은 국내 임상검사실의 외부정도관 리 결과를 바탕으로 복합 항체 동정 및 감별능력 현황에 대하여 파 악해보고자 한다.

2016년부터 2020년까지 대한임상검사정도관리협회 수혈의학 분야 신빙도조사 결과 중 수혈 특수항체검사-비예기항체 동정검 사에 참가한 기관들의 보고된 답안을 대상으로 분석을 시행하였 다. 연구 포함기준은 의도된 정답이 복합 항체인 경우 또는 복합 항체를 정답으로 보고한 경우이며, 각 경우에 대해 정답률, 오답 률, 및 오답 유형 등을 분석하였다.

분석결과를 Table 1 및 Table 2에 제시했다. 5년 동안 시행된 10 차례의 신빙도조사에서 총 20검체에 대한 비예기항체 동정검 사가 진행되었으며, 연구 포함기준을 만족하는 경우는 모두 7검체 였다. 이 중 의도된 정답은 단일 항체였는데, 복합 항체로 답한 기
관이 있는 경우가 5 검체(Table 1), 반대로 의도된 정답은 복합 항 체였으나 단일 항체로 답한 기관이 있는 경우가 2검체였다(Table 2). 의도된 정답이 단일 항체였을 경우 정답률은 $87.9 \%-97.5 \%$ 수준이었다. 오답의 유형은 항체의 특이성을 다른 항원에 대한 항 체로 잘못 동정한 경우, 의도하지 않은 추가 항체를 보고한 경우, 비예기항체의 존재 자체를 검출하지 못한 경우 등 다양하게 나타 났다. 2017년 2차와 2019년 2차 모두 항-C 항체가 의도된 정답이 었는데 항-E 항체를 같이 보고한 기관이 각각 11 기관, 14 기관으로 적지 않았다. 두 번의 복합 항체에 대한 정도관리 결과를 살펴보 면, 2018년 2차에서 항-C 항체와 항-D 항체를 모두 검출하여야 하 는데, 항-D 항체만 검출하거나 비예기항체를 검출하지 못한 기관 이 일부 있었다. 특히 2020년 1회차 BBS20-01 검체는 의도된 정 답이 항-C 항체와 항-e 항체가 같이 존재하는 것이었는데, 항-e 항 체만 단독으로 보고한 기관이 39기관(28.9\%)으로 확인되었다.

전체적으로 $\mathrm{Rh}$ 계열 항체에서 단일 또는 복합 항체의 구분을 어 려워하는 기관이 많은 것으로 나타났다. 이는 Rh CcEe의 항원형 분포상 대개 $\mathrm{c}$ 항원 양성인 혈구는 $\mathrm{E}$ 항원도 양성이며 e 항원 양 성인 혈구는 C 항원도 양성인 경우가 많아 항체 동정을 위한 상용 화된 혈구 패널에서 대개 이 두 항원형을 분리하여 패널을 구성하 지 않는 경우가 많기 때문이다. 따라서 단순히 혈구 응집의 유무 만 감안하여 비예기항체 동정검사를 진행하는 경우는 항-c 항체

\section{Corresponding author: Dae-Hyun Ko}

Department of Laboratory Medicine, Asan Medical Center, University of Ulsan College of Medicine, 88 Olympic-ro 43-gil, Songpagu, Seoul 05505, Korea

Tel +82-2-3010-4504, E-mail daehyuni1118@amc.seoul.kr

Received: August 13, 2021; Revised: August 27, 2021; Accepted: August 30, 2021

This is an Open Access article distributed under the terms of the Creative Commons Attribution Non-Commercial License (http://creativecommons.org/licenses/by-nc/4.0) which permits unrestricted non-commercial use, distribution, and reproduction in any medium, provided the original work is properly cited. 
Table 1. Number (\%) of participants and unacceptable responses in domestic external quality assessment for whom the intended responses were a single antibody (2016 to 2020)

\begin{tabular}{|c|c|c|c|c|c|c|c|}
\hline Year & Trial & Specimen & $\begin{array}{l}\text { Intended } \\
\text { response }\end{array}$ & $\begin{array}{c}\text { No. of } \\
\text { participants }\end{array}$ & Acceptable (\%) & Unacceptable (\%) & $\begin{array}{l}\text { Unacceptable } \\
\text { responses }(\mathrm{N})\end{array}$ \\
\hline 2016 & 1 st & BBS-16-01 & Anti-Fy(a) & 118 & $115(97.5)$ & $3(2.5)$ & $\begin{array}{l}\text { Anti-Fy(a)+anti-N (2) } \\
\text { Anti-E (1) }\end{array}$ \\
\hline 2017 & 1 st & BBS-17-01 & Anti-C & 122 & $119(97.5)$ & $3(2.5)$ & $\begin{array}{l}\text { Anti-C+anti-S (2) } \\
\text { Anti-E (1) }\end{array}$ \\
\hline 2017 & 2nd & BBS-17-04 & Anti-c & 123 & $109(88.7)$ & $14(11.3)$ & $\begin{array}{l}\text { Anti-c+anti-E (11) } \\
\text { Anti-c+anti-Jk (b) (1) } \\
\text { Not detected (2) }\end{array}$ \\
\hline 2019 & $2 n d$ & BBS-19-05 & Anti-c & 132 & $116(87.9)$ & $16(12.1)$ & $\begin{array}{l}\text { Anti-c+anti-E (14) } \\
\text { Anti-E (1) } \\
\text { Anti-K (1) }\end{array}$ \\
\hline 2020 & 2nd & BBS-20-04 & Anti-E & 135 & $133(98.5)$ & $2(1.5)$ & Anti-c+anti-E (2) \\
\hline
\end{tabular}

Table 2. Number (\%) of participants and unacceptable responses in domestic external quality assessment for whom the intended responses were combined antibodies (2016 to 2020)

\begin{tabular}{cccccccc}
\hline Year & Trial & Specimen & $\begin{array}{c}\text { Intended } \\
\text { response }\end{array}$ & $\begin{array}{c}\text { No. of } \\
\text { participants }\end{array}$ & Acceptable (\%) & Unacceptable (\%) & $\begin{array}{c}\text { Unacceptable } \\
\text { responses (N) }\end{array}$ \\
\hline 2018 & 2nd & BBS-18-04 & Anti-C+anti-D & 126 & $123(97.6)$ & $3(2.4)$ & $\begin{array}{c}\text { Anti-D (2) } \\
\text { Not detected (1) }\end{array}$ \\
2020 & 1st & BBS-20-01 & Anti-C+anti-e & 135 & $93(68.9)$ & $42(31.1)$ & $\begin{array}{l}\text { Anti-C (2) } \\
\text { Anti-e (39) } \\
\text { Anti-C+others (1) }\end{array}$ \\
\hline
\end{tabular}

만 존재하는 경우와 항-c 및 항-E 항체가 공존하는 경우, 그리고 항-e 항체만 존재하는 경우와 항-e 및 항-C 항체가 공존하는 경우 를 구분하기 어려울 수 있다. 이 경우 두 항체의 공존 여부를 배제 하기 위한 추가 검사를 실시하여야 항체를 정확하게 동정할 수 있 다. 대표적인 수혈의학 관련 기관인 미국혈액은행협회(American Association of Blood Banks)에서도 항체의 특이성이 동정된 후 에 단일 항체로 의심되더라도 특정 혈구(selected red cells)와 반 응을 시켜 그 특이성을 확정할 것을 권장하고 있고, 특히 복합 항 체를 배제할 수 없는 경우에는 더욱 그렇다[2]. 복합 항체를 의심 할 수 있는 상황들로는 (1) 항체동정검사 결과를 단일 항체의 반응 성으로 설명할 수 없는 경우, (2) 반응성이 혈구에 따라 또는 검사 반응상(phase)에 따라 다른 경우, (3) 단일 항체의 특이성을 확정 하기 위한 검사에서 예기치 않은 반응성을 나타내는 경우, (4) 항 체 동정용 혈구 패널 전체에 반응을 보이는데 환자와 표현형이 유 사한 혈구와는 반응을 보이지 않는 경우 등이 있다[2]. 검사실에서 시행할 수 있는 방법으로 예를 들어 항-C와 항-e가 공존하는지 또 는 항-e만 존재하는지 감별이 안 되는 경우, 해당 검체와 C+e- 표 현형 혈구를 반응시켜 응집이 일어나는지 여부를 관찰하는 방법 이 있다. 또 다른 방법으로는 C-e+ 혈구로 검체를 흡착하면 항-e 항체는 제거되어 남은 검체로 비예기항체 동정검사를 다시 시행
하는 방법이 있다. 원하는 표현형의 혈구를 찾기 위해서는 검사실 에서 가지고 있는 환자의 잔여 검체에 항원형 검사를 실시하여 찾 거나, 수혈용 적혈구의 교차시험용 관분절 일부를 사용할 수 있다. 한국인에서 Rh CcEe 항원형의 분포상 C 항원 양성/e 항원 음성 은 $0.5 \%, \mathrm{C}$ 항원 음성/e 항원 양성은 $5.2 \%$ 존재하므로 이를 감안 하여 각 검사실에서 기관별 상황에 맞는 전략을 취하면 될 것이다 [3].

복합 항체를 정확하게 감별하는 것은 수혈 전 검사뿐 아니라 산 전 검사에서도 매우 중요하다. 수혈 전 검사로서 항체동정검사를 진행할 경우, 복합 항체 여부가 정확하게 판별이 되지 않더라도 가 능한 항원들을 모두 피해서 수혈용 혈액제제를 선택할 수 있으나, 산전 검사에서 동정되는 항체들은 각 항체별로 태아신생아용혈질 환(hemolytic disease of the fetus and newborn)의 위험도가 다르기 때문에 복합 항체 여부를 정확하게 구분하지 않으면 산모 에게 제대로 된 처치를 하기 어려워질 가능성이 있다. 국내에서 자 주 동정되는 비예기항체 빈도 중 복합 항체가 적지 않다는 점을 감 안한다면 이러한 점은 더욱 중요하다[4]. 따라서 국내 검사기관들 에서 항체동정검사를 시행하면서 복합 항체 여부를 배제하기 어려 울 때에는 반드시 그 특이성을 확정하기 위한 추가적인 검사를 시 행하는 것이 필요할 것으로 생각된다. 


\section{ORCID}

Hee-Jeong Youk

https://orcid.org/0000-0003-3528-7729

Jin Seok Kim

https://orcid.org/0000-0003-0166-2084

Yousun Chung
Sang-Hyun Hwang https://orcid.org/0000-0003-3201-5728

Heung-Bum Oh https://orcid.org/0000-0001-6728-4640

Hyungsuk Kim https://orcid.org/0000-0002-0574-9200

Dae-Hyun Ko https://orcid.org/0000-0002-9781-0928

\section{REFERENCES}

1. Yang JJ, Kim JS, Lim YA, Kim H, Ko DH. Annual report of the Korean Association of External Quality Assessment Service on Transfusion Medicine (2019). Lab Med Qual Assur 2020;42:112-20.

2. Er LS, Bailey DJ. Identification of antibodies to red cell antigens. In: Cohn CS, Delaney M, Johnson ST, Katz LM, editors. Technical manual. 20th ed. Bethesda (MD): Association for the Advancement of Blood \& Biotherapies, 2020:389-428.

3. Han KS, Park KU, Song EY. Blood group. In: Han KS, Park KU, Song EY, editors. Transfusion medicine. 4th ed. Seoul: Korea Medical Book Publisher, 2014:100-9.

4. Ok SJ, Kim SY, Kim IS, Lee EY, Kim HH. Eleven years' experience with unexpected antibody screening tests including a Di(a) cell in transfusion candidates. Korean J Blood Transfus 2013;24:64-70. 